This version July 2008 - accepted to appear in Research Policy (in press).

\title{
Engaging the scholar: three types of academic consulting and their impact on universities and industry
}

Markus PERKMANN and Kathryn WALSH

Wolfson School of Mechanical and Manufacturing Engineering

Loughborough University

Loughborough LE11 3TU (UK)

m.perkmann@lboro.ac.uk

k.walsh@lboro.ac.uk

phone +441509227674

\begin{abstract}
We present a conceptual framework of academic consulting and explore its impacts on universities and the benefits to innovating firms. We distinguish between three types of academic consulting: opportunity-driven, commercialization-driven and research-driven. Exploring the implications of these different types, firstly, we postulate that consulting has limited impact on biasing academic research towards more 'applied' themes. Secondly, while we expect research-driven consulting activities to be positively associated with research productivity, opportunity-driven consulting will have a negative impact. Thirdly, we differentiate between different functions of academic consulting for different types of firms.
\end{abstract}

Keywords: academic consulting, faculty consulting, university-industry relations, commercialization, science technology interface 


\section{Introduction}

While in some quarters debates are raging about the possibility of 'engaged scholarship' (Van De Ven and Johnson, 2006), the relevance of academic knowledge has long been established in many areas of economic activity. Much research has focused on technology transfer and academic entrepreneurship (Shane, 2004). Yet as the multiplex nature of university-industry relationships is increasingly recognized, attention has shifted to forms of interaction that involve direct collaboration between academics and industry (Cohen et al., 2002; Perkmann and Walsh, 2007). Such collaboration encompasses licensing with inventor collaboration (Agrawal, 2006), university-industry research centres (Adams et al., 2001) and collaborative research (Behrens and Gray, 2001).

Among these collaborative forms of interaction, academic consulting is widely practiced yet it appears largely uncaptured and unstudied (Bercovitz and Feldman, 2006; Cohen et al., 2002). What role does consulting play within the overall spectrum of university-industry interactions? A detailed reading of the literature reveals an incomplete picture, specifically concerning the relationship between academics’ research and their consulting engagements. Some authors report positive feedback effects between research productivity and involvement with industrial partners (Mansfield, 1995; Van Looy et al., 2004). Others are sceptical as they point to the detractive effects of industry collaboration for academic research (Behrens and Gray, 2001; Slaughter and Leslie, 1997). Surveys also suggest that at least some academics hesitate to engage with industry, fearing that commercial orientation might distract from academic relevance (Howells et al., 1998; Lee, 1996). 
These inconsistencies suggest that academic consulting is perhaps practiced in different forms and for different reasons. The primary objective we pursue in this paper is to develop a typology of academic consulting that distinguishes between different ways in which academics offer their expertise to external organizations. We then develop propositions relating to the effects of different types of academic consulting.

Specifically, we address three questions. Firstly, to what extent does consulting change the direction of research towards more 'applied' topics, hence potentially undermining the long-term benefits of autonomous, curiosity-driven research (Merton, 1973)? Secondly, does consulting distract academics from doing research or do they in fact go hand in hand? Commonly, consulting is regarded as rather unrelated to state-of-the-art academic research (Howells et al., 1998) yet, simultaneously, consulting appears to be practiced by high-performing academics (Mansfield, 1995). Thirdly, how does academic consulting contribute to innovation processes within firms? While much emphasis in the literature is on the transfer of technology as an output of leading-edge academic research, consulting may involve the mobilization of more common expertise required especially at the latter stages of the innovation cycle (Feller, 1999).The question is then what role consulting plays for firms, and what firms are most likely to profit from this specific type of knowledge transfer.

We pursue our objective by developing a theoretical paper building on prior literature whereby we focus on academic consulting in the science and technology fields. Existing conceptual models and empirical evidence are inconclusive, indicating the need for theoretical exploration and synthesis (Kilduff, 2006). We develop a threefold typology that is derived from academics’ motivation to engage in consulting and distinguishes between opportunity-driven, commercialization-driven and research-driven consulting. Subsequently, we address each of the research questions and develop propositions on 
the impact of these different forms of academic consulting. We conclude with implications for universities and policy-makers.

\section{Identifying types of academic consulting}

We define academic consulting as the provision of a service by academics to external organizations on commercial terms. This may involve providing advice, resolving problems as well as generating or testing new ideas. Consulting is usually provided individually by academics. By contrast, contract research tends to be collectively performed by research groups although the distinction is blurred in practice (Schmoch, 1999).

Academic consulting is widely practiced (D'Este and Patel, 2007; Meyer-Krahmer and Schmoch, 1998). Many universities encourage staff to provide consulting by allowing them to spend usually $20 \%$ of their time on outside activities (Schmoch, 1999). In the UK, total university income from consulting translated into an average of GBP 2,458 per academic staff member in 2006 (HEFCE, 2007). ${ }^{1}$ An average US full-time faculty member earned an additional annual income of approximately USD 2,200 in 2003 . $^{2}$ These figures underestimate the real volume as many engagements may not be disclosed to university administrators. Observers estimate that more than half of engineering faculty at the top 20 US research universities spend $10-15 \%$ of their time on consulting (Abramson et al., 1997: 101). Consulting has also been held responsible for the considerable share of US patents filed by academics yet assigned to firms rather than universities (Thursby et al., 2007).

\footnotetext{
${ }^{1}$ Compiled from HEFCE (2007) and www.hefce.ac.uk (accessed 4/2/2008).

${ }^{2}$ National Center for Education Statistics (http://nces.ed.gov, accessed: 10/04/07)
} 
In the following, we develop a typology based on existing literature. Underlying the typology is the assumption that academics are motivated to engage in consulting by different rationales. Consulting constitutes discretionary individual behaviour and different motivations will result in different activities. We postulate that consulting can be motivated by income considerations, the desire to commercialize inventions or the intention to generate research opportunities. Apart from motivation, two additional aspects appear relevant for characterizing different types of consulting. Firstly, one can expect differences in the type of knowledge exchanged or generated during consulting activities. Secondly, we consider the structure of the relationships within which consulting activities are pursued (Table 1).

(Table 1 about here)

\subsection{Opportunity-driven consulting}

Academics might engage in consulting by responding to personal income opportunities. Such an income-oriented view is predominant in an older US debate (Boyer and Lewis, 1984; Rebne, 1989). It is also implicit in life cycle theories predicting that junior researchers focus on building an academic career while they capitalize on their expertise by engaging with industry later on (Stephan and Levin, 1992). For academics, the marginal cost of providing consulting is relatively low as they possess the required expertise already, allowing them to appropriate rents.

Academics are specialists in certain areas of expertise and firms therefore engage them to resolve specific problems (Gibbons and Johnston, 1974). In this view, consulting differs from other university-industry relationships in that it mobilizes expertise that is 
commonly held within academic communities (Agrawal and Henderson, 2002). Rather than commercializing the latest discoveries, it leverages 'old science' (Gibbons and Johnston, 1974; Rosenberg, 1994). Such consulting resolves problems and provides improvements rather than suggesting new project ideas or pioneering new design configurations (Cohen et al., 2002). To achieve this, academics will not need much prior knowledge about the client organization and its technology, and - in terms of the relationship - assignments might therefore be short-term and time-bound. Opportunity-driven consulting is not necessarily complementary with academic research. Indeed, it is usually seen to be of lesser academic value (Boyer and Lewis, 1984) as it does not directly contribute to research or teaching. A UK survey suggests that the barriers for academics to engage in consulting are somewhat different from those for collaborative research (Howells et al., 1998). The statement that consultancy work was 'not interesting' was ranked top, and 'lack of career impact' was ranked third among the barriers to consulting activities indicating that academics perceive a trade-off between consulting and their primary interests.

Yet some dissonant evidence suggests that opportunity-driven consulting is not the only logic inherent in academic consulting. Belgian data indicate that researchers involved in contract research generally published more than their 'pure' academic colleagues while their research activities were not visibly skewed towards more 'applied' themes (Van Looy et al., 2004). Others argued that academics’ decisions to engage in consulting were not primarily driven by financial motives and that consulting academics are at least as academically active as their non-consulting peers (Boyer and Lewis, 1984; Patton and Marver, 1979). Below, we therefore consider two alternative views on consulting. 


\subsection{Commercialization-driven consulting}

Consulting can also be linked to academics’ efforts to commercialize their own technologies (Agrawal, 2006; Shane, 2004). Hiring inventors as consultants constitutes an obvious option for a licensee to access their expertise. Inventor involvement is critical for the commercial success of university-generated technologies which are often embryonic. According to a US survey, 71\% of outlicensed inventions (including to spin-offs) required inventor assistance for being successfully commercialized (Thursby et al., 2001). Inventors commonly retain their faculty position and work with the commercializing entity via consulting, contract research, personnel exchange and advisory board presence (Goldfarb and Henrekson, 2003). In addition to spin-off companies, large existing firms licensing university technology also benefit from inventor collaboration. A US study showed that approximately $40 \%$ of university licensees indicated that the technologies could not be successfully commercialized without faculty co-operation (Thursby and Thursby, 2004). Agrawal (2006) found that for two thirds of a sample of MIT-owned licenses, academic inventors were involved in the further development of the technology.

Consulting motivated by commercialization strategies differs from opportunity-driven consulting in several respects. Inventions will usually be the output of academic research, possibly pursued over long periods of time. Motivationally, therefore academics will be driven more intrinsically by the desire to see their inventions flourish as an extension of their research. Secondly, the relationship between academics and clients is likely to be a stable arrangement, possibly comprising financial ties (Boyd and Bero, 2000). The remit of the relationship focuses on a specific project, implying that the academic might have a position akin to an external member of a development team who can be called upon when needed. 


\subsection{Research-driven consulting}

In a third scenario, consulting activities are directly linked to academics’ research projects. Academics often maintain consulting relationships with firms supporting their research. Mansfield (1995) reported that in all industries other than pharmaceuticals, over half of a sample of highly industry relevant academics said that the problems and ideas they worked on in their government-funded research often developed out of consulting. Murray’s (2002) work on tissue engineering also points to a distinct research-driven logic. She found, like others (Agrawal and Henderson, 2002; Gittelman and Kogut, 2003), that there is limited network membership overlap between paperauthoring academics and patent-authoring researchers, suggesting that 'inventors' are different from 'researchers'. The researchers, however, 'co-mingle' with industry in various ways, including consulting, advisory board membership and sponsored research (Murray, 2002). Similarly, consulting was found to be a significant predictor of all other forms of academic entrepreneurship (Louis et al., 1989).

Rather than opportunity-driven income seeking, such consulting is motivated by the desire to gain insights into industry 'challenges' or access research materials. Cohen et al. (2002) found that firms use academic consulting often in conjunction with other 'open science’ mechanisms, i.e. conferences, informal interaction and joint research. This result suggests that such consulting activities are research-driven, in line with 'Mertonian’ objectives (Merton, 1973). The ensuing relationships will be strongly socially embedded and characterized by ongoing barter-like interactions (Kreiner and Schultz, 1993). Therefore, while formal consulting assignments in this context are remunerated, some occasional and informal advice may be provided in an untraded manner (Faulkner and Senker, 1994). 
In terms of the knowledge mediated in this type of relationship, one can expect a strong emphasis on interactive learning and knowledge co-production (Rosenberg, 1994).

Research-driven consulting represents one of the channels through which instrumentation and techniques are developed via mutual interaction between industry and academia (Rosenberg, 1992). Equally, the deep understanding of a firm’s technology trajectory built through continuous interaction enables academics to provide advice on strategic R\&D decisions. Some scientists have 'scientific taste’, allowing them to judge the likely payoff of different lines of research and advise firms concerning their relative merits (Zucker et al., 1998).

Any typology is only valuable if it can be used for sharply distinguishing between empirical phenomena. For our typology, this could be done by using questionnaire scales assessing the incentives underlying academics' consulting. If additional income is indicated as the main motivator, this can be classified as opportunity-driven consulting. Commercialization-driven consulting is indicated by academics' desire to contribute to the commercial success to their own inventions. This may well result in additional income but the consulting activity will be distinct in that it is likely to be much closer to an academics' core research interest. Finally, research-driven consulting is indicated by academics' intention to learn from industry, access research opportunities and build contacts.

\section{Discussion: effects of academic consulting}

We now consider implications for universities and firms. Our propositions are summarized in Table 2.

(Table 2 about here) 


\subsection{The impact of consulting on the direction of research}

Some observers fear that increased industry involvement may shift academics' research towards more applied topics with long-term detrimental effects on cumulative basic science. Blumenthal et al. (1986) reported that a third of biotechnology researchers with industrial funding - compared to 7\% without industrial funding - chose topics for their short-term research programmes that they expected to have some commercial impact. Two thirds of surveyed US university-industry research centres stated that industry exerted a 'moderate to strong influence' on the direction of their research - however this was dependent on the goals they set themselves (Cohen et al., 1994). Gulbrandsen and Smeby (2005) found that Norwegian researchers with industry funding performed less basic research than researchers with no such external funds.

However, Hicks and Hamilton (1999) found that the share of basic research at universities remained unchanged between 1981 and 1995 while university patenting increased significantly. Other studies (Godin and Gingras, 2000; Brooks and Randazzese, 1999) reported no evidence of industrial influence on the research direction of collaborative research. Thursby and Thursby (2002) found that increases in university licensing were largely due to universities' greater commercialization efforts rather than changes in research direction.

These ambiguous results suggest that the degree of industrial bias might be determined by specific characteristics of interactions in each instance. For instance, it seems conceivable that publications derived from industry-funded contract research or collaborative research might be more applied as project objectives result from a 
compromise between industrial and academic objectives (Webster, 1994). As for consulting, our typology suggests a differentiated assessment.

Opportunity-driven consulting has the least thematic and relational connection with research. In thematic terms, the activity requested by clients does not constitute research but the application of scientific knowledge to a specific problem (Salter and Martin, 2001). Outputs from consulting are therefore rarely suitable or available to be published. In relational terms, the researcher will in many cases not have a researchrelated connection with the firm. Both aspects suggest that engagement in opportunitydriven consulting will not per se bias an academic's research towards more applied topics. Similarly, commercialization-driven consulting is unlikely to skew the research interests of an academic as they are a follow-on activity to inventive activity - at best the bias might already be present. In other words, it is the prior inventive activity that is at the core of academics' research interests and not the follow-on consulting. We therefore postulate:

Proposition 1: Academics’ involvement in opportunity-driven and commercializationdriven consulting does not influence the direction of their research towards more applied research topics.

To operationalize this proposition, one may relate a measure of involvement in either type of consulting to a measure expressing the degree of basicness of academics' publication output. If a significant negative relationship between both measures was found, the proposition would need to be rejected. For research-driven consulting matters appear more complex. Here it is useful to consider under what circumstances academics and industry have a mutual interest to 
collaborate on research-related matters. Stokes (1997) argued that some research aims to both resolve practical problems and generate fundamental scientific understanding. Such 'Pasteur' research differs from either applied research (not requiring fundamental understanding), or basic research (not aimed at problem solving). For instance, this applies to some biotechnology, computer science or aeronautical engineering. While research outputs are utilized as inputs to both research and technology development (Nelson, 2004), problems arising in technology development provide agendas for follow-on research activities (Rosenberg, 1992). As much technological development occurs in industry, this circular relationship between science and application requires constant interaction between the two realms.

These considerations suggest that much research-driven consulting is linked to such Pasteur-type research. If research is recursively intertwined with technological development, academics are uniquely placed to offer advice on further development while industry provides them with research challenges, data, materials and instrumentation. Hence one would predict that academics involvement in researchdriven consulting would not make their research more applied. Simultaneously, one would expect research-oriented consulting to be practiced mostly in Pasteur-type fields, i.e. those fields that combine fundamental scientific understanding with practical usage considerations.

Proposition 2a: Involvement in research-driven consulting does not influence the direction of academics’ research towards more applied research topics. 2b: Academics specializing in Pasteur-type fields carry out more research-oriented consulting than other researchers. 
For operationalization, one might relate a measure of engagement in research-driven consulting (e.g. days per year) to a measure expressing an academic’s specialization in Pasteur-type research, such as their focus on fields with a high proportion of industry scientists appearing as journal authors. The null hypothesis for 2a is that the volume of research-oriented consulting by an academic influences the direction of their research. The null hypothesis for $2 \mathrm{~b}$ is that academics specializing in Pasteur-type fields do not differ from other academic in terms of the volume of engagement in research-based consulting.

\subsection{The impact of consulting on research productivity}

Previous work has examined the impact of academics' commercial activities on their research performance. Engaging in academic entrepreneurship and technology transfer can be compatible with high scientific productivity (Zucker and Darby, 1996). Agrawal and Henderson (2002) found that higher patenting rates for scientists can be associated with higher citation impact for journal publications. An older literature on US factually consulting found that academics engaging in more consulting were also more productive in terms of research (Boyer and Lewis, 1984; Louis et al., 1989; Rebne, 1989).

This evidence suggests considerable complementarities between academic output and involvement in commercialization activities. This view has however been contested by some authors (Slaughter and Leslie, 1997) and appears counter-intuitive for two reasons specifically for consulting. First, trade-offs in terms of time and effort can be expected. Second, secrecy issues might restrict publishing from industrial work, leading to a tension between the requirements of 'open science' and commercial appropriability considerations (Murray and Stern, 2007). This is especially relevant for consulting 
activities where outputs usually belong to industrial clients. Both these limitations make it unlikely that data or insights from consulting directly generate novel publishable material.

However, involvement with firms may increase the quality and quantity of academics' research due to increased resources (Zucker and Darby, 1996). A resource-based view is supported by case study evidence highlighting that spin-off companies are sometimes used to fund further academic research by their founders (Meyer, 2003). Consulting also often goes hand in hand with sponsored or collaborative research funded or co-funded by industrial partners (Mansfield, 1995).

In addition to resource mobilization, consulting can enable access to research-critical elements such as materials, data drawn from real industrial processes or information on problems and challenges. This logic will be particularly relevant in the 'Pasteur' disciplines of applied science and engineering. Moreover, resource mobilization and access to research opportunities are likely to be present particularly in situations where researchers and firms are linked through long-term, socially embedded relationships. From the viewpoint of the firm, sponsored or collaborative research is a risky undertaking with no immediate payoff and funds are therefore likely to be given only to trusted partners who ensure confidentiality and are willing to provide formal or informal consulting.

To summarize, such circumstances are likely to prevail for research-driven and, to a degree, commercialization-driven consulting. Opportunity-driven consulting, by contrast, is less likely to generate these research benefits as it may not occur within the context of wider relationships. As results are usually not publishable, involvement in opportunity-driven consulting competes with time spent on research and teaching and will therefore have a negative impact on publishing output by the academic. 
Proposition 3a: Involvement in research-driven consulting, and to a lesser extent, commercialization-driven consulting, are positively associated with research productivity.

3b: Involvement in opportunity-driven consulting is negatively associated with research productivity.

To operationalize these propositions, one could relate a time-lagged measure of academics’ research productivity to a measure of involvement in consulting activities. The null hypothesis for 3a is that research-driven or commercialization-driven consulting do not promote research output. The null hypothesis for $3 \mathrm{~b}$ is that involvement in opportunity-driven consulting does not hinder research output.

\subsection{The role of academic consulting for firms}

Why do firms engage academics as consultants? The answer is most obvious for commercialization-driven consulting provided by academic inventors to the licensees of university-generated technology. As information contained in patents is often insufficient for successfully exploiting technology, particularly in novel industries, valuable expertise tends to be tacit and complex, and hence naturally exclusive (Zucker et al., 2002). Although the underlying knowledge might not by definition be uncodifiable, it might be too costly to do so against its perceived value, meaning that it remains 'latent' (Agrawal, 2006). Personal involvement via commercialization-driven consulting represents a mechanism for firms to ‘capture' such latent knowledge (Zucker et al., 2002). This enables firms to enjoy first-mover advantages before the expertise diffuses via codification. Given the self-interest of the academic consultants in 'their' 
technology they are unlikely to be disinterested judges of the risk associated with a chosen path. Partly because of 'moral hazard' on the part of the inventor (Jensen and Thursby, 2001), commercialization-driven consulting is unlikely to be of strategic, pathselecting nature.

By contrast, research-driven consulting is attractive to firms that routinely engage with university researchers, for instance in pharmaceuticals and aerospace (Cohen et al., 2002) and generally in high-technology industries. Among these, particularly the larger firms with formal R\&D operations have the required absorptive capacity (Cohen and Levinthal, 1990). The rationale for accessing university-based research for these companies is to extend in-house basic research and provide windows on emerging technologies (Santoro and Chakrabarti, 2002). Such organizations often pursue innovation strategies with high degrees of complexity and uncertainty (Tidd, 2001). The use of external academic expert judgment within such selection processes represents one of the mechanisms to reduce uncertainty (Pavitt, 2005). Academics therefore play a role, similar to entrepreneurship, as 'knowledge filter’ (Ács et al., 2004), bridging the link between knowledge creation and its purposeful exploitation. Opportunity-driven consulting follows a different logic. It may be used by a broader range of firms and may be overlooked by studies focusing on large R\&D-active firms. Demand for opportunity-driven academic consulting is likely to exist particularly within smaller firms. Large firms with differentiated $R \& D$, design or production engineering departments have less need for the type of problem solving capability and issue-centred advice implicit in opportunity-driven consulting. In smaller firms, innovation is often more informal and relying on external sources due to the fixed costs involved in maintaining specialist expertise and equipment. 
However, for many smaller firms, the main sources of innovation are either internal or within their vertical supply chains (Mansfield, 1991). For instance, both 'specialized supplier' and 'supplier-dominated firms' rely on their vertical value chains for their innovative inputs (Pavitt, 1984) and are hence less likely to use academics as external collaborators. By contrast, 'new technology-based firms' (NTBFs) focus on specific proprietary technologies as the basis for their products and services (Bollinger et al., 1983). NTBFs are the most likely clients for opportunity-based consulting activities as their focus is primarily on development rather than basic R\&D. Such firms, that tend to be start-ups in sectors such as electronics, instruments, biotechnology and software, may resort to hiring academics for problem-solving and testing concepts. We synthesise our discussion below:

Proposition (4a) Commercialization-driven consulting furthers the development of university technologies licensed by firms;

(4b) Academics' involvement in research-driven consulting is positively associated with client firms’ engagement in basic R\&D;

(4c) Academics' involvement in opportunity-driven consulting is positively associated with client firms' status as new technology-based firms.

Proposition 4a can be operationalized by relating the success rate of licensed technology - measured for instance by royalties generated - to the volume of consulting provided by inventors. The null hypothesis is that the contribution of commercialisation-driven consulting to successful technology development does not differ from cases where no consulting or merely non-inventor consulting is provided. Proposition 4b can be operationalized by relating the volume of academics' research-based based consulting to 
a measure of their clients' engagement in long-term R\&D (Laursen and Salter, 2004).

The null hypothesis is that research-based consulting by academics is not promoted by their client firms’ engagement in R\&D. Finally, proposition 4c can be operationalized by relating the volume of academics’ opportunity-driven consulting to a measure indicating their clients' status as new technology based firm, such as being a start-up in high-tech sectors. The null hypothesis is that opportunity-driven consulting is not promoted by firms' status as new technology-based firms.

\section{Conclusions}

We identified three types of academic consulting: opportunity-driven, commercialization-driven and research-driven. The typology allows us to evaluate the varying impact of different consulting activities on universities and firms. First, contrary to fears expressed by some observers, we contend that consulting has limited impact on the direction of academic research towards more 'applied' themes. Secondly, we argue that consulting is positively associated with academics' research productivity for research-driven and, to a lesser extent, commercialization-driven consulting while involvement in opportunity-driven consulting has a negative impact. Thirdly, we differentiate between different roles of academic consulting for firms.

Commercialization-driven consulting allows firms to accelerate development along a chosen path of in-sourced technology. Research-driven consulting is used mainly by large firms in research-intensive sectors for externally informing and validating the direction of their R\&D and long-term product development efforts. Opportunity-driven consulting is commissioned mainly by new technology-based firms seeking to compensate for lacking expertise or equipment. 
Future empirical research, apart from testing our propositions, could investigate whether academics engage in several of these consulting activities simultaneously or successively during their career. While junior faculty may appreciate the additional income generated by opportunity-driven consulting, senior faculty may engage more in research-driven consulting within their wider research network. As for practical implications, our analysis suggests universities should look more closely at what type of consulting activities they promote. While commercialization and research-driven consulting are likely to enhance research productivity, opportunitydriven consulting activities might not do so. Particularly universities with high ambitions for academic excellence could therefore gain from differentiating between different types of consulting activities. In turn, particularly research-intensive firms using technology based on 'Pasteur' disciplines are likely to benefit from academic consulting as this is where the interests of both parties are best aligned. Finally, there are implications for science and technology policy. The trade-off between some types of consulting and high research productivity suggests a dual strategy in terms of promoting industry involvement for academics. While opportunity-driven consulting will be less interesting to highly research-productive universities, it might make policy sense to promote it within less research-oriented universities. For the economy as a whole, this constitutes the volume segment of making universitygenerated knowledge available to a broader audience of firms, without compromising curiosity-driven research.

Acknowledgements: A previous version was presented at the Academy of Management Meeting Annual Meeting 2008 in Philadelphia. We gratefully appreciate comments by John Bessant, Julian Birkinshaw, Pablo d'Este, David Gann, Pietro Micheli, Andy 
Neely, Stephen Pavelin and two anonymous reviewers. Research was carried out as part of the 'Innovation and Productivity Grand Challenge’ (IPGC) programme. Funding provided by the UK Engineering and Physical Sciences Research Council (EPSRC) and the Economic and Social Research Council (ESRC) through the Advanced Institute of Management Research (AIM).

\section{References}

Abramson, H. N., Encarnação, J., Reid, P. P., Schmoch, U. (Eds.), 1997. Technology transfer systems in the United States and Germany: lessons and perspectives. Washington, National Acad. Press.

Ács, Z. J., Audretsch, D., Braunerhjelm, P., Carlsson, B., 2004. The missing link: the knowledge filter and entrepreneurship in endogenous growth. London, Centre for Economic Policy Research.

Adams, J. D., Chiang, E. P., Starkey, K., 2001. Industry-university cooperative research centers. The Journal of Technology Transfer 26 (1 - 2), 73-86.

Agrawal, A., 2006. Engaging the inventor: Exploring licensing strategies for university inventions and the role of latent knowledge. Strategic Management Journal 27 (1), 63-79.

Agrawal, A., Henderson, R. M., 2002. Putting patents in context: Exploring knowledge transfer from MIT. Management Science 48 (1), 44-60.

Behrens, T. R., Gray, D. O., 2001. Unintended consequences of cooperative research: impact of industry sponsorship on climate for academic freedom and other graduate student outcome. Research Policy 30 (2), 179-199.

Bercovitz, J., Feldman, M., 2006. Entrepreneurial universities and technology transfer: A conceptual framework for understanding knowledge-based economic development. Journal of Technology Transfer 31 (1), 175-188.

Blumenthal, D., Gluck, M., Louis, K. S., Stoto, M. A., Wise, D., 1986. Universityindustry research relationships in biotechnology - implications for the university. Science 232 (4756), 1361-1366. 
Bollinger, L., Hope, K. and Utterback, J. M., 1983. A review of literature and hypotheses on new technology-based firms. Research Policy 12(1): 1-14.

Boyd, E. A., Bero, L. A., 2000. Assessing faculty financial relationships with industry: a case study. JAMA 284, 2209-2214.

Boyer, C. M., Lewis, D. R., 1984. Faculty consulting: responsibility or promiscuity? The Journal of Higher Education 55 (5), 637-659.

Brooks, H., Randazzese, L., 1999. University-industry relations: the next four years and beyond, in: Branscomb, L., Keller, J. (Eds.), Investing in innovation: Creating a research and innovation policy that works. Cambridge (MA), MIT Press, pp. 361-399.

Cohen, S. B., Florida, R., Coe, W. R., 1994. University-industry partnerships in the US. Pittsburgh, Carnegie-Mellon University.

Cohen, W. M., Levinthal, D. A., 1990. Absorptive capacity: a new perspective on learning and innovation. Administrative Science Quarterly 35 (1), 128-152.

Cohen, W. M., Nelson, R. R., Walsh, J. P., 2002. Links and impacts: the influence of public research on industrial R\&D. Management Science 48 (1), 1-23.

D'Este, P., Patel, P., 2007. University-industry linkages in the UK: what are the factors determining the variety of interactions with industry? Research Policy 36 (9), 1295-1313.

Faulkner, W., Senker, J., 1994. Making sense of diversity: public-private sector research linkage in three technologies. Research Policy 23 (6), 673-695.

Feller, I., 1999. The American university system as a performer of basic and applied research, in: Branscomb, L. M., Kodama, F., Florida, R. (Eds.), Industrializing knowledge: university-industry linkages in Japan and the United States. Cambridge (MA), MIT Press, pp. 65-101.

Gibbons, M., Johnston, R., 1974. The roles of science in technological innovation. Research Policy 3 (3), 220-242.

Gittelman, M., Kogut, B., 2003. Does good science lead to valuable knowledge? Biotechnology firms and the evolutionary logic of citation patterns. Management Science 49 (4), 366-382.

Godin, B., Gingras, Y., 2000. Impact of collaborative research on academic science. Science and Public Policy 27, 65-73. 
Goldfarb, B., Henrekson, M., 2003. Bottom-up versus top-down policies towards the commercialization of university intellectual property. Research Policy 32 (4), 639-658.

Gulbrandsen, M., Smeby, J.-C., 2005. Industry funding and university professors' research performance. Research Policy 34 (6), 932-950.

HEFCE, 2007, Higher education business and community interaction survey 2006. London: Higher Education Funding Council for England.

Hicks, D., Hamilton, K., 1999. Does university-industry collaboration adversely affect university research? Issues in Science and Technology 15 (4), 74-75.

Howells, J., Nedeva, M., Georghiou, L., 1998, Industry-academic links in the UK. PREST, University of Manchester.

Jensen, R., Thursby, M., 2001. Proofs and prototypes for sale: the licensing of university inventions. American Economic Review 91 (1), 240-259.

Kilduff, M., 2006. Editors comments: publishing theory. Academy of Management Review 31 (2), 252-255.

Kreiner, K. and Schultz, M., 1993. Informal collaboration in R\&D. The formation of networks across organizations. Organization Studies 14 (2): 189-209.

Laursen, K. and Salter, A., 2004. Searching high and low: what types of firms use universities as a source of innovation? Research Policy 33 (8): 1201-1215.

Lee, Y. S., 1996. 'Technology transfer' and the research university: A search for the boundaries of university-industry collaboration. Research Policy 25 (6), 843863.

Louis, K. S., Blumenthal, D., Gluck, M., Stoto, M. A., 1989. Entrepreneurs in academe: an exploration of behaviors among life scientists. Administrative Science Quarterly 34 (1), 110-131.

Mansfield, E., 1991. Academic research and industrial innovation. Research Policy 20, $1-12$.

Mansfield, E., 1995. Academic research underlying industrial innovations: sources, characteristics, and financing. Review of Economics and Statistics 77 (1), 55-65.

Merton, R. K., 1973. The sociology of science. Theoretical and empirical investigations. University of Chicago Press, Chicago, London.

Meyer-Krahmer, F., Schmoch, U., 1998. Science-based technologies: universityindustry interactions in four fields. Research Policy 27 (8), 835-851. 
Meyer, M., 2003. Academic entrepreneurs or entrepreneurial academics? Researchbased ventures and public support mechanisms. R\&D Management 33 (2), 107115.

Murray, F., 2002. Innovation as co-evolution of scientific and technological networks: exploring tissue engineering. Research Policy 31 (8,9), 1389-1403.

Murray, F., Stern, S., 2007. Do formal intellectual property rights hinder the free flow of scientific knowledge? An empirical test of the anti-commons hypothesis. Journal of Economic Behavior and Organization 63 (4), 648-687.

Nelson, R. R., 2004. The market economy, and the scientific commons. Research Policy 33 (3), 455-471.

Patton, C. V., Marver, J. D., 1979. Paid consulting by American academics. Educational Record 60 (2), 175-184.

Pavitt, K., 1984. Sectoral patterns of technical change: towards a taxonomy and a theory. Research Policy 13 (6), 343-373.

Pavitt, K., 2005. Innovation processes, in: Fagerberg, J., Mowery, D., Nelson, R. (Eds.), Oxford Handbook of Innovation. Oxford, Oxford University Press, pp. 86-147.

Perkmann, M., Walsh, K., 2007. University-industry relationships and open innovation: towards a research agenda. International Journal of Management Reviews 9 (4), 259-280.

Rebne, D., 1989. Faculty consulting and scientific knowledge - a traditional universityindustry linkage. Educational Administration Quarterly 25 (4), 338-357.

Rosenberg, N., 1992. Scientific instrumentation and university research. Research Policy 21 (4), 381-390.

Rosenberg, N., 1994. Exploring the black box: technology, economics, and history. Cambridge; New York, Cambridge University Press.

Santoro, M. D., Chakrabarti, A. K., 2002. Firm size and technology centrality in industry-university interactions. Research Policy 31 (7), 1163-1180.

Salter, A. J. and Martin, B. R., 2001. The economic benefits of publicly funded basic research: a critical review. Research Policy 30 (3), 509-532.

Schmoch, U., 1999. Interaction of universities and industrial enterprises in Germany and the United States - a comparison. Industry and Innovation 6 (1), 51-68.

Shane, S. A., 2004. Academic entrepreneurship: university spinoffs and wealth creation. Cheltenham ; Northampton, MA, Edward Elgar. 
Slaughter, S., Leslie, L. L., 1997. Academic capitalism: politics, policies and the entrepreneurial university. Baltimore, MD, Johns Hopkins University Press.

Stephan, P. E., Levin, S. G., 1992. Striking the mother lode in science: the importance of age, place, and time. Oxford, Oxford University Press.

Stokes, D. E., 1997. Pasteur's quadrant: basic science and technological innovation. Washington, D.C., Brookings Institution Press.

Thursby, J., Fuller, A., Thursby, M., 2007. US faculty patenting: inside and outside the university. NBER Working Paper 13256.

Thursby, J. G., Thursby, M. C., 2002. Who is selling the ivory tower? Sources of growth in university licensing. Management Science 48 (1), 90-104.

Thursby, J. G., Thursby, M. C., 2004. Are faculty critical? Their role in universityindustry licensing. Contemporary Economic Policy 22 (2), 162-178.

Thursby, J. G. A., Jensen, R. A., Thursby, M. C. A., 2001. Objectives, characteristics and outcomes of university licensing: a survey of major US universities. Journal of Technology Transfer 26 (1), 59-72.

Tidd, J., 2001, Innovation management in context: environment, organization and performance, in, International Journal of Management Reviews, Vol. 3: Blackwell Publishing Limited.

Van De Ven, A. H., Johnson, P. E., 2006. Knowledge for theory and practice. Academy of Management Review 31 (4), 802-821.

Van Looy, B., Ranga, M., Callaert, J., Debackere, K., Zimmermann, E., 2004. Combining entrepreneurial and scientific performance in academia: towards a compounded and reciprocal Matthew-effect? Research Policy 33 (3), 425-441.

Webster, A., 1994. University-corporate ties and the construction of research agendas. Sociology 28 (1), 123-142.

Zucker, Lynne G., Darby, Michael R., 1996. Star scientists and institutional transformation: patterns of invention and innovation in the formation of the biotechnology industry. Proceedings of the National Academy of Sciences 93 (23), 12709-12716.

Zucker, L. G., Darby, M. R., Armstrong, J., 1998. Geographically localized knowledge: spillovers or markets? Economic Inquiry 36 (1), 65-86. 
Zucker, L. G., Darby, M. R., Armstrong, J. S., 2002. Commercializing knowledge: university science, knowledge capture, and firm performance in biotechnology. Management Science 48 (1), 138-153. 
TABLE 1

Models of Academic Consulting

\begin{tabular}{|l|l|l|l|}
\hline & Motive & Relationship & Type of knowledge \\
\hline Opportunity-driven & Income & Short-term & Openly accessible, \\
& & & specialist expertise \\
\hline -driven & development & & Tacit expertise \\
\hline Research-driven & Research & Long-term, & Strategic judgment, \\
& opportunities & embedded & know-what \\
\hline
\end{tabular}


TABLE 2

\section{Impacts of different types of academic consulting}

\begin{tabular}{|c|c|c|c|c|}
\hline & $\begin{array}{l}\text { Shift away from } \\
\text { basic research }\end{array}$ & $\begin{array}{l}\text { Impact on academic } \\
\text { productivity }\end{array}$ & Contribution & Benefiting firms \\
\hline $\begin{array}{l}\text { Commercialization- } \\
\text { driven }\end{array}$ & no & o & $\begin{array}{l}\text { Enabling and } \\
\text { accelerating } \\
\text { development }\end{array}$ & $\begin{array}{l}\text { Licensees (up-start technology companies and } \\
\text { existing companies) }\end{array}$ \\
\hline Research-driven & no & + & $\begin{array}{l}\text { 'Windows' on new } \\
\text { technologies, strategic } \\
\text { advice }\end{array}$ & Large, science and technology-intensive firms \\
\hline
\end{tabular}


